\author{
Jozef STAHOVEC ${ }^{1}$ \\ Jozef BEŇO ${ }^{2}$ \\ Marek VRABEL ${ }^{3}$
}

\title{
INVESTIGATION OF THE CUSP HEIGHT WHEN BALL-END MILLING FORM SHAPED SURFACES
}

\begin{abstract}
This paper presents a model for cusp height in the ball-end milling process. In many milling operations, the cutting tool performs step over and makes adjacent cuts to complete machining of any feature. As a result, a small cusp of material, called a cusp height, will remain between these cuts on the surrounding walls or on the machined surface if a ball-end mill is used. This procedure presents application of software to evaluate cusp height in milling process. The height of cusp is examined in surfaces having different curvature ratio and different orientation. The model for the mathematical prediction of the cusp height has been developed in terms of axial and radial depth of cut, surface curvature and tool diameter. The application of the DOE technique by Taguchi gives the process parameter values that lead to the minimum machining time and achievement of the desired surface texture.
\end{abstract}

Keywords: milling, cutting conditions, cusp height, textured

\section{Introduction}

Sculptured surface are widely used in the design of complex product with moulds and dies features. These surfaces are often produced by 3- and 5-axis computer numerical control machine tools using ball-end milling cutter. The factors which affect the surface finish in the ball-end milling process are generally the cutting speed, feed rate, depth of cut, width of cut etc. Arizmendi [1] presents a model for the topography prediction of ball-end milled surfaces, considering the tool parallel axis offset. In this model, the equations of cutting edges trajectories and the envelope equation of the material swept by the tool are derived. Chen et al. [2] presents the model, simulation and experimental verification of the scallop formation on the machined surface in the ball-end milling

\footnotetext{
${ }^{1}$ Autor do korespondencji/corresponding author: Jozef Stahovec, Technical University in Košice, Mäsiarska 74, 04001 Košice, Slovakia, tel.: +421 556023502, e-mail: jozef.stahovec @ tuke.sk

2 Jozef Beňo, Technical University in Košice, Mäsiarska 74, 04001 Košice, Slovakia, e-mail: branislav.duleba@tuke.sk

${ }^{3}$ Marek Vrabel', Technical University in Košice, Mäsiarska 74, 04001 Košice, Slovakia, e-mail: marek.vrabel@tuke.sk
} 
process. The geometric shape and the dynamical change of the ball-end cutting edges, path-interval scallop and feed-interval scallop are generated on the machined surface. Iqbal [3] studies the effects of workpiece inclination angle and radial depth of cut upon effective cutting speed and cusp height and, subsequently, upon surface roughness. Workpiece's inclination angle proved to be the most influential parameter for surface roughness. Its higher values provided better surface finish because of avoidance of cutting at the tool's centre. Feng [4] presents a new approach for the determination of efficient tool path in the machining of sculptured surfaces using 3-axis ball-end milling. The objective is to keep the cusp height constant across the machined surface such that excess tool paths are minimized. Chuang [5] presents the cusp height dependent by the z- level depth and slope of the part surface. Cusp height data of ball-end milling from Table 1 characterize the former and the latter.

Table 1. Some cusp height data from ball-end milling

\begin{tabular}{|l|l|c|c|}
\hline \multicolumn{1}{|c|}{ Source } & \multicolumn{1}{c|}{ Type of surface } & $\begin{array}{c}\text { Tool diameter } \\
{[\mathbf{m m}]}\end{array}$ & $\begin{array}{c}\text { Cusp height } \\
{[\mathbf{m m}]}\end{array}$ \\
\hline Cao [6] & helicoidal surface, saddle surface & 12 and 25 & $0.0018 \div 0.0150$ \\
\hline Feng [4] & sculptured surface & 25,4 & 0.5000 \\
\hline Cheen [2] & sculptured surface & 10 and 14 & $0.0063 \div 0.0450$ \\
\hline Chuang [5] & concave surface & 4 & 0.0100 \\
\hline Iqbal [3] & inclined surface & 8 & 0.0038 \\
\hline Larigue [7] & concave surface & 9 & 0.0306 \\
\hline López [8] & stamping dies & 12 & 0.0300 \\
\hline Mizugaki [9] & spherical surface & 5 & 0.0239 \\
\hline Quinstat [10] & convex and concave surface & 5 & 0.0091 \\
\hline
\end{tabular}

\section{Cusp height}

In many milling operations, the cutting tool must perform step over and make several adjacent cuts to complete machining of any feature. As a result, a small cusp of material, called a cusp height, will remain between these cuts on the surrounding walls or on the machined surface if a ball-end mill is used. The data for experimental design are shown in Table 2. Cusp height is representing as maximum height of the profile $(R z)$. Cusp height is calculated based on the following formula:

$$
\operatorname{ch}=\frac{D}{2}-\sqrt{\left(\frac{D}{2}\right)^{2}-\left(\frac{a_{e}}{2}\right)^{2}}
$$

Figure 1 shows the generation the cusp height and basic factors in this process. 
Table 2. Experimental design matrix and results

\begin{tabular}{|c|c|c|c|c|c|c|c|}
\hline \multirow{3}{*}{ No } & \multicolumn{3}{|c|}{ Control factors } & \multicolumn{4}{|c|}{$\operatorname{ch}[\mu \mathrm{m}]$} \\
\hline & \multirow{2}{*}{$\begin{array}{c}k \\
\mathbf{m m}\end{array}$} & \multirow[b]{2}{*}{$\begin{array}{c}a p \\
\mathbf{m m}\end{array}$} & \multirow[b]{2}{*}{$\begin{array}{c}a e \\
\mathbf{m m}\end{array}$} & \multirow{2}{*}{$\begin{array}{l}\text { experimental } \\
\text { value }\end{array}$} & \multicolumn{3}{|c|}{ predicted value } \\
\hline & & & & & $\begin{array}{c}\text { initial mod- } \\
\text { el }\end{array}$ & $\begin{array}{l}\text { improved } \\
\text { model }\end{array}$ & error \\
\hline 1 & -0.100 & 0.50 & 1.00 & 14.16 & 13.8429 & 13.6407 & 0.5193 \\
\hline 2 & -0.100 & 0.50 & 1.00 & 12.85 & 13.8429 & 13.6407 & -0.7907 \\
\hline 3 & -0.100 & 0.50 & 1.00 & 13.31 & 13.8429 & 13.6407 & -0.3307 \\
\hline 4 & -0.100 & 1.00 & 1.50 & 15.40 & 14.8698 & 14.6677 & 0.7323 \\
\hline 5 & -0.100 & 1.00 & 1.50 & 12.16 & 14.8698 & 14.6677 & -2.5077 \\
\hline 6 & -0.100 & 1.00 & 1.50 & 18.05 & 14.8698 & 14.6677 & 3.3823 \\
\hline 7 & -0.100 & 1.50 & 0.50 & 7.13 & 6.5874 & 6.3852 & 0.7448 \\
\hline 8 & -0.100 & 1.50 & 0.50 & 6.76 & 6.5874 & 6.3852 & 0.3748 \\
\hline 9 & -0.100 & 1.50 & 0.50 & 6.08 & 6.5874 & 6.3852 & -0.3052 \\
\hline 10 & -0.067 & 0.50 & 1.00 & 13.94 & 13.3968 & 13.6560 & 0.2840 \\
\hline 11 & -0.067 & 0.50 & 1.00 & 13.72 & 13.3968 & 13.6560 & 0.0640 \\
\hline 12 & -0.067 & 0.50 & 1.00 & 14.08 & 13.3968 & 13.6560 & 0.4240 \\
\hline 13 & -0.067 & 1.00 & 1.50 & 13.49 & 14.8943 & 15.1534 & -1.6634 \\
\hline 14 & -0.067 & 1.00 & 1.50 & 15.99 & 14.8943 & 15.1534 & 0.8366 \\
\hline 15 & -0.067 & 1.00 & 1.50 & 13.92 & 14.8943 & 15.1534 & -1.2334 \\
\hline 16 & -0.067 & 1.50 & 0.50 & 5.68 & 6.0722 & 6.3313 & -0.6513 \\
\hline 17 & -0.067 & 1.50 & 0.50 & 6.35 & 6.0722 & 6.3313 & 0.0187 \\
\hline 18 & -0.067 & 1.50 & 0.50 & 5.92 & 6.0722 & 6.3313 & -0.4113 \\
\hline 19 & 0.050 & 0.50 & 1.00 & 13.30 & 13.7670 & 13.7100 & -0.4100 \\
\hline 20 & 0.050 & 0.50 & 1.00 & 13.66 & 13.7670 & 13.7100 & -0.0500 \\
\hline 21 & 0.050 & 0.50 & 1.00 & 14.00 & 13.7670 & 13.7100 & 0.2900 \\
\hline 22 & 0.050 & 1.00 & 1.50 & 16.58 & 16.9326 & 16.8756 & -0.2956 \\
\hline 23 & 0.050 & 1.00 & 1.50 & 18.80 & 16.9326 & 16.8756 & 1.9244 \\
\hline 24 & 0.050 & 1.00 & 1.50 & 15.70 & 16.9326 & 16.8756 & -1.1756 \\
\hline 25 & 0.050 & 1.50 & 0.50 & 6.44 & 6.1971 & 6.1401 & 0.2999 \\
\hline 26 & 0.050 & 1.50 & 0.50 & 6.39 & 6.1971 & 6.1401 & 0.2499 \\
\hline 27 & 0.050 & 1.50 & 0.50 & 5.82 & 6.1971 & 6.1401 & -0.3201 \\
\hline
\end{tabular}

Fig. 1. Geometrical elements of the machined surface: $a_{e}-$ width of cut, $a_{p}$ - depth of cut, ch-cups hight, $D$ - tool diameter, $D_{e f}$ - effective tool diameter, $R$ - toll radius

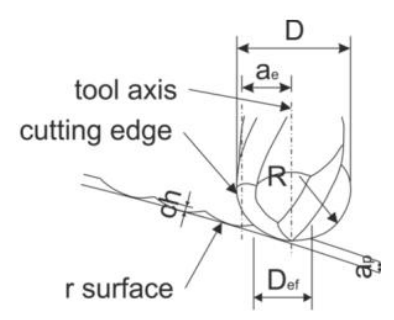

\section{Response surface method}

Response surface method was used to establish the mathematical relationship between the response - cusp height and the various machining parameters - depth of cut, width of cut and curvature of the work surface. Mathematical model based on the response surface of the second order was used to express 
effect of milling process on cusp height. The cusp height was measured by portable surface roughness tester Surftest SJ-301. Virtual machining was carried out in terms of the Taguchi L27 experimental design. Factors affecting the quality of machined surface are shown in Fig. 2. Taguchi designs are based on a fact that not all factors that cause variability can be controlled in practice and these uncontrollable factors are referred to as noise factors. Taguchi designs attempt to identify controllable factors (control factors) that minimize the effect of the noise factors. During experimentation, noise factors are manipulated to make variability occur and then to find optimal control factor settings that make the process or product robust, or resistant to variation from the noise factors. Figure 3 shows the main effect plot form for milling of the variable shape of the machined surface. Basically, an increase in width of cut makes the cusp height increase. Factors that affect the mean response are depth of cut, width of cut and curvature of the machined surface and they are shown in Table 3.

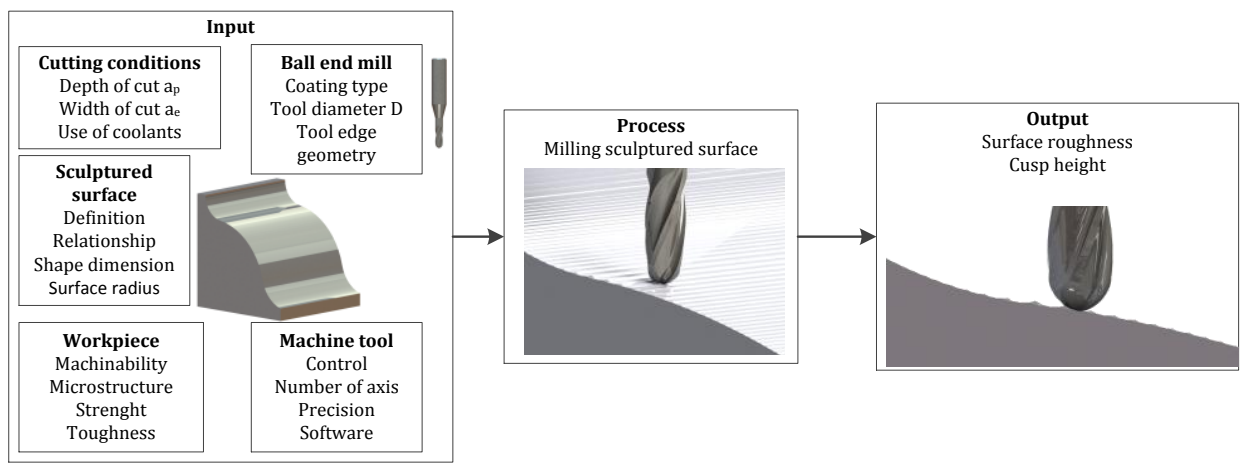

Fig. 2. Factors affecting the quality of the product

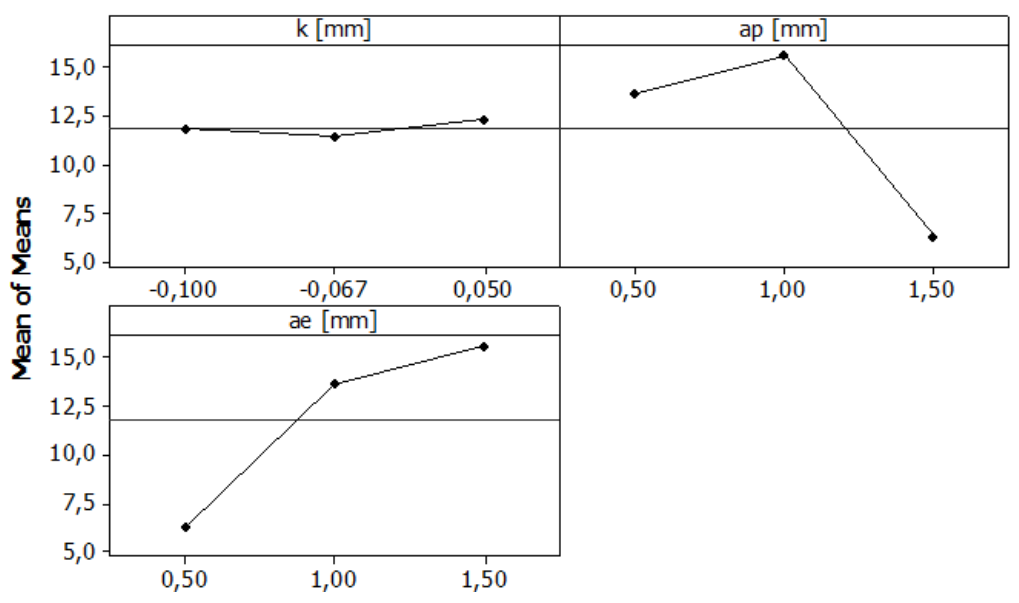

Fig. 3. Main effects plot for means by Taguchi 
Experiments were performed as ball-end milling of the test sample $80 \times 50$ x $30 \mathrm{~mm}$. The tool used is $8 \mathrm{~mm}$ diameter carbide ball-end mill with dwo flutes (Iscar tools). The data given in the Table 3 are analyzed by using a software package MiniTab 16. The regression analysis and its coefficients is presented in Table 4. Expressions in Table 5 are used as the initial model and they include all the linear, square and interactions terms. The empirical equation for predicting the initial cusp height ch is:

$$
\begin{aligned}
c h= & 6,66+(-19,408 \cdot k)+\left(-3,342 \cdot a_{p}\right)+\left(8,247 \cdot a_{e}\right)+\left(111,192 \cdot k^{2}\right)+ \\
& +\left(8,108 \cdot k \cdot a_{p}\right)+\left(20,408 \cdot k \cdot a_{e}\right)
\end{aligned}
$$

$\mathrm{R}-\mathrm{Sq}(\operatorname{adj})$ is indicating that our model can predict within $91,72 \%$ accuracy. The empirical equation for predicting the improved cusp height ch is:

$$
\begin{aligned}
c h= & 7,111+(-24 \cdot k)+\left(-3,342 \cdot a_{p}\right)+\left(8,247 \cdot a_{e}\right)+\left(8,108 \cdot k \cdot a_{p}\right)+ \\
& +\left(20,408 \cdot k \cdot a_{e}\right)
\end{aligned}
$$

Analysis of variance (ANOVA) in Table 5 lists the sources of variation, their degrees of freedom, the total sum of squares and the mean squares. The analysis of variance also includes the F-statistics and P-values. Use of these data is aimed to determine whether the predictors or factors are significantly related to the response. Use of the P-value aims to determine whether a factor is significant; typically compare against an alpha value of 0.05 . If the P-value is lower than 0.05 then the factor is significant. Data from ANOVA are also used in the analysis of the regression and DOE. The initial model also indicates that the curvature of the machined surface is insignificant factor for having less influence on cusp height. Surface plot of cusp height in Fig. 4 shows the relation between two main factors $a_{p}$ and $a_{e}$ which depend the cusp height resulting from milling. The normal probability plot in Fig. 5 shows a clear pattern indicating that all the factors and their interaction given in Table 4 are affecting the cusp height. The so called versus fits in Figure 5 indicate that the maximum variation of -2 to 4 which shows the high correlation does exist between fitted value and observed value. Relations between various factors are shown in interaction plot for cusp height in Fig. 6. A desirability value $d$ means $0 \leq d \leq 1$ and the value of $d$ increases as the "desirability" of the corresponding response increases. The factor settings with maximum desirability are considered to be the optimal parameter conditions. It is revealed that highest desirability could be obtained at middle curvature $(-0.0136 \mathrm{~mm})$, high depth of cut $(1.5 \mathrm{~mm})$ and low width of cut $(0.5$ $\mathrm{mm})$. The goal was to minimize the cusp height $(5.7516 \mu \mathrm{m})$. The desirability of optimization has been calculated as 1.00 all the parameters are within their working range. The differences between measured and predicted responses cusp height for ball nose end milling process are illustrated in Fig. 7. The samples from end-ball milling process are shown in Fig. 8. 
Table 3. Response table for means

\begin{tabular}{|c|c|c|c|}
\hline Level & $\begin{array}{c}\boldsymbol{k} \\
{[\mathbf{m m}]}\end{array}$ & $\begin{array}{c}\boldsymbol{a}_{\boldsymbol{p}} \\
{[\mathbf{m m}]}\end{array}$ & $\begin{array}{c}\boldsymbol{a}_{\boldsymbol{e}} \\
{[\mathbf{m m}]}\end{array}$ \\
\hline 1 & 11.767 & 13.669 & 6.286 \\
\hline 2 & 11.454 & 15.566 & 13.669 \\
\hline 3 & 12.299 & 6.286 & 15.566 \\
\hline Delta & 0.844 & 9.280 & 9.280 \\
\hline Rank & 3 & 1.5 & 1.5 \\
\hline
\end{tabular}

Table 4. Estimated regression coefficients for cusp height

\begin{tabular}{|l|c|c|c|c|}
\hline \multicolumn{1}{|c|}{ Term } & Coef & SE Coef & T value & P value \\
\hline Constant & 7.111 & 1.3799 & 5.123 & 0.000 \\
\hline$k$ & -24.000 & 18.3367 & -1.309 & 0.205 \\
\hline$a_{p}$ & -3.342 & 0.7806 & -4.281 & 0.000 \\
\hline$a_{e}$ & 8.247 & 0.7806 & 10.565 & 0.000 \\
\hline$k \cdot a_{p}$ & 8.108 & 10.3728 & 0.782 & 0.443 \\
\hline$k \cdot a_{e}$ & 20.408 & 10.3728 & 1.967 & 0.062 \\
\hline$S=1.22642$ & \multicolumn{2}{|c|}{ PRESS $=52.3959$} & \multicolumn{2}{c|}{-} \\
\hline$R-S q=93.31 \%$ & \multicolumn{2}{|c|}{$R-S q(\mathrm{pdr})=88.91 \%$} & $=91.72 \%$ \\
\hline
\end{tabular}

Table 5. Analysis of variance for cusp height

\begin{tabular}{|l|c|c|c|c|c|c|}
\hline \multicolumn{1}{|c|}{ Source } & DF & Seq SS & Adj SS & Adj MS & F value & P value \\
\hline Regression & 5 & 440.872 & 440.872 & 88.174 & 58.62 & 0 \\
\hline Linear & 3 & 434.968 & 351.887 & 117.296 & 77.98 & 0 \\
\hline Interaction & 2 & 5.904 & 5.904 & 2.952 & 1.96 & 0.165 \\
\hline Residual Error & 21 & 31.586 & 31.586 & 1.504 & - & - \\
\hline Total & 26 & 472.458 & - & - & - & - \\
\hline
\end{tabular}

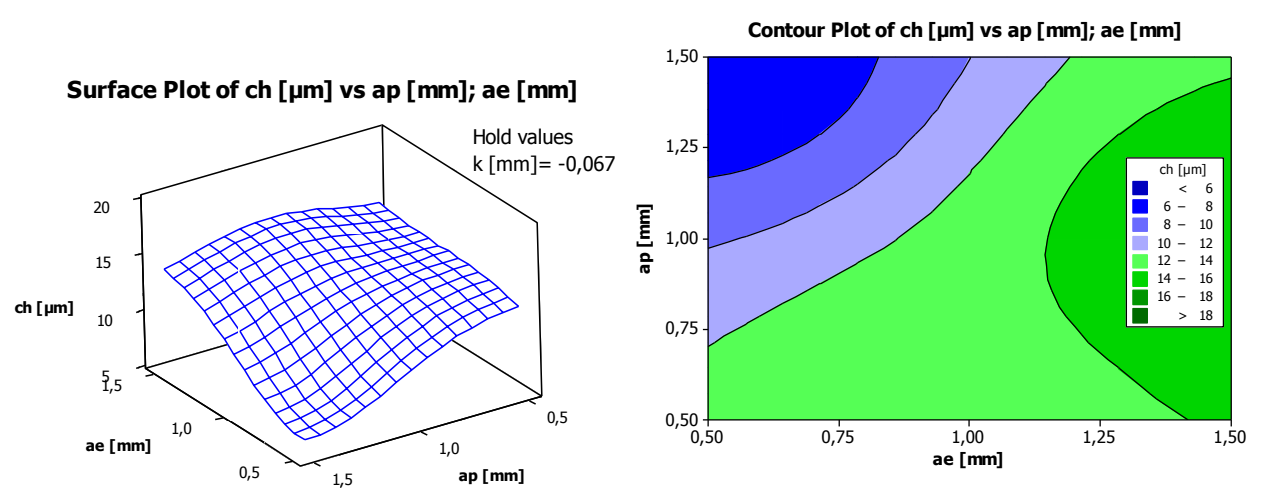

Fig. 4. Surface and contour plot of cusp versus both $a_{e}$ and $a_{p}$ 

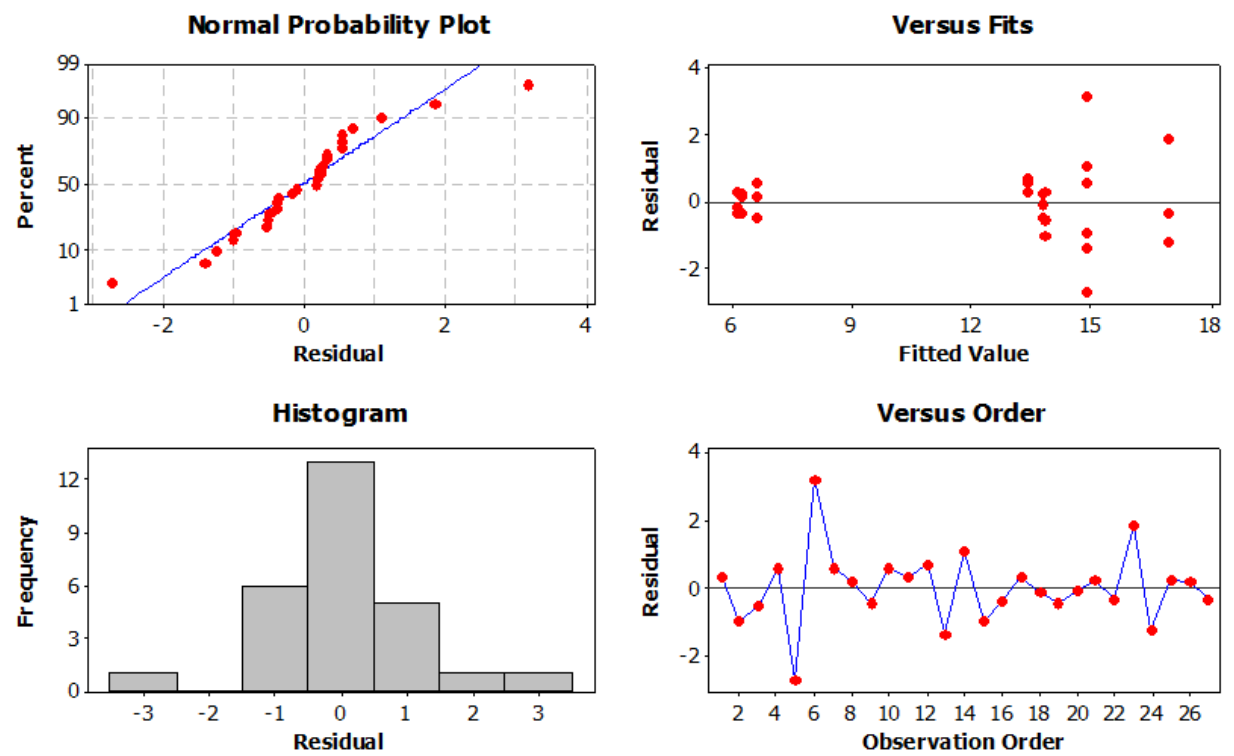

Fig. 5. Residual plots for cusp height

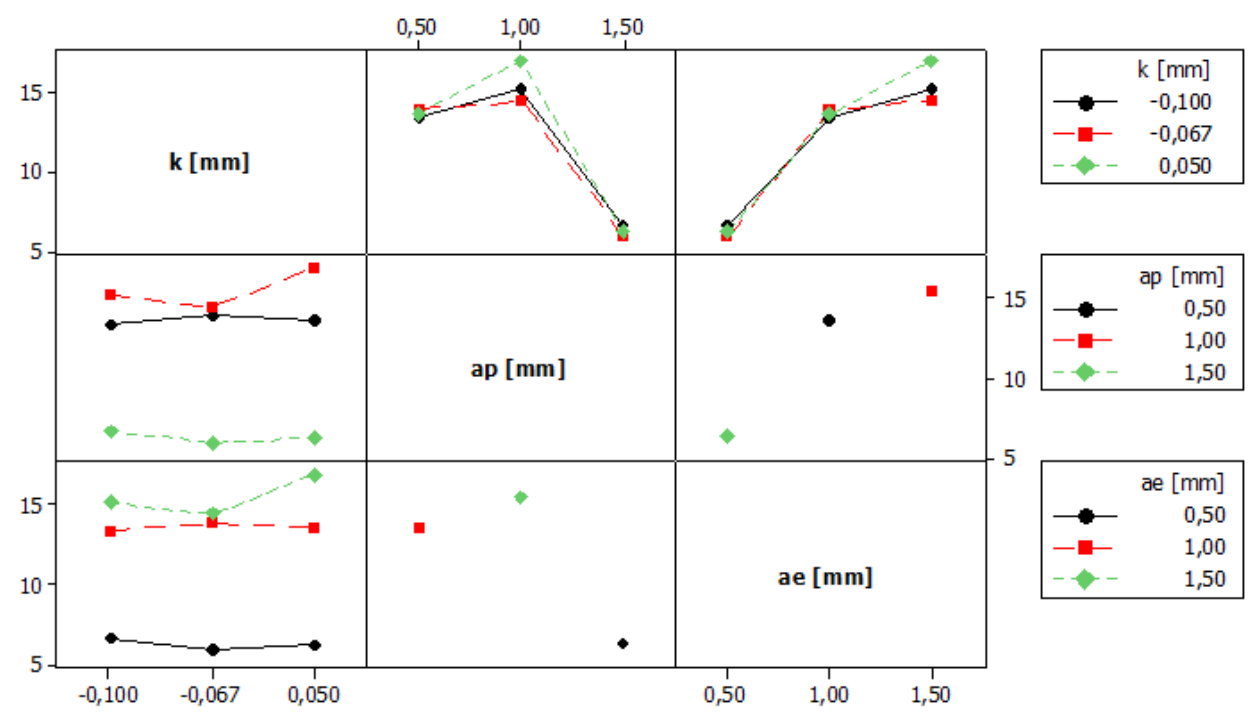

Fig. 6. Interaction plot for cusp height

A desirability value $d$ means $0 \leq d \leq 1$ and the value of $d$ increases as the "desirability" of the corresponding response increases. The factor settings with maximum desirability are considered to be the optimal parameter conditions. 
It is revealed that highest desirability could be obtained at middle curvature $(-0.0136 \mathrm{~mm})$, high depth of cut $(1.5 \mathrm{~mm})$ and low width of cut $(0.5 \mathrm{~mm})$. The goal was to minimize the cusp height $(5.7516 \mu \mathrm{m})$. The desirability of optimization has been calculated as 1.00 all the parameters are within their working range. The differences between measured and predicted responses cusp height for ball nose end milling process are illustrated in Fig. 7. The samples from endball milling process are shown in Fig. 8 .

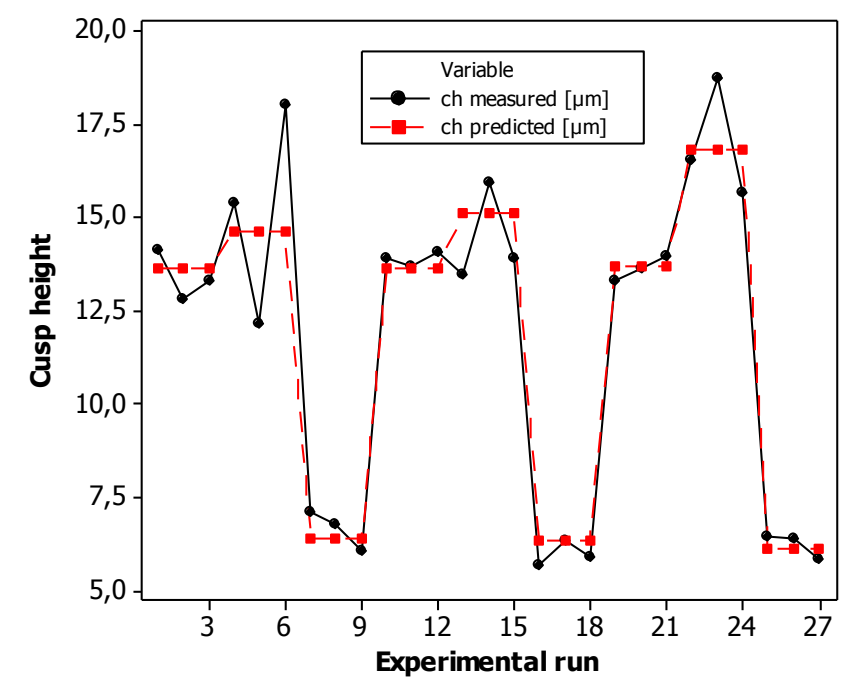

Fig. 7. Comparison of measured and modeled values for the cusp height

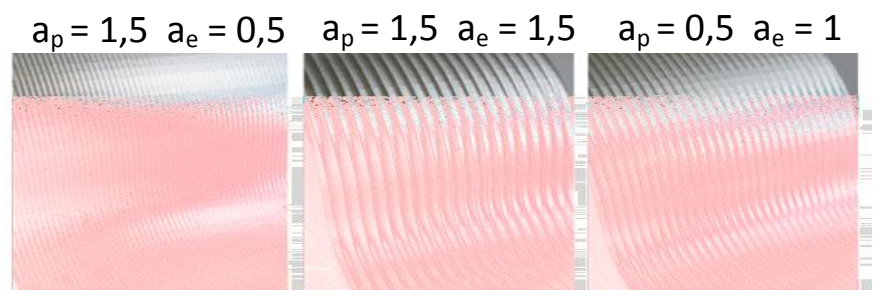

Fig. 8. Manufactured samples

\section{Conclusion}

Step over or width of cut affects the cusp height. Cusp height is the theoretical surface finish produced by successive tool paths made by a radius tool. Larger step over or a smaller cutter diameter produces a larger cusp height; i.e. a rougher finish. For the best surface finish, the use of the largest diameter tool is 
possible at the lowest practical width of cut. Path-interval cusp height can be reduced by reducing the pick value between cutting paths. The reduced pick between cutting paths, however, increased number of the cutting paths. The use of modern high-speed cutting technology makes it possible to increase feed rate and feed per tooth without increasing machining time. The highest cusp height was achieved in joining circle. In finishing operations of sculptured surfaces by milling with three axis machines it is possible to achieve a better surface finish (roughness and cusp height) and a lower machining time when using the ball nose milling cutters.

\section{References}

[1] Arizmendi M., Fernández J., Lacalle L.N.L., Lamikiz A., Gil A., Sánchez J.A., Campa F.J., Veiga F.: Model development for the prediction of surface topography generated by ball-end mills taking into account the tool parallel axis offset, Experimental validation, CIRP Annals - Manuf. Technol., 57 (2008), 101-104.

[2] Chen J.-S., Huang Y.-K., Chen M.-S.: A study of the surface scallop generating mechanism in the ball-end milling process, Int. J. Mach. Tools Manuf., 45 (2005), 1077-1084.

[3] Iqbal A., Ning H., Khan I., Liang L., Dar N.U.: Modeling the effects of cutting parameters in MQL-employed finish hard-milling process using D-optimal method, J. Mat. Proc. Technol., 199 (2008), 379-390.

[4] Feng H.-Y., Huiwen L.: Constant scallop-height tool path generation for three-axis sculptured surface machining, Computer-Aided Design, 34 (2002), 647-654.

[5] Chuang C.-M., Yau H-T.: A new approach to z-level contour machining of triangulated surface models using fillet end mills, Computer Aided Design, 37 (2005), 1039-1051.

[6] Cao L-X., Gong H., Liu J.: The offset approach of machining free form surface: Part 1: Cylindrical cutter in five-axis NC machine tools, J. Mat. Proc. Technol., 174 (2006), 298-304.

[7] Lartigue C., Thiebaut F., Maekawa T.: CNC tool path in terms of B-spline curves, Computer Aided Design, 33 (2001), 307-319.

[8] López de Lacalle L.N., Lamikiz A., Sánchez J.A., Arana J.L.: Improving the surface finish in high speed milling of stamping dies, J. Mat. Proc. Technol., 123 (2002), 292-302.

[9] Mizugaki Y., Kikkawa K., Terai H., Hao M.: Theoretical estimation of machined surface profile based on cutting edge movement and tool orientation in ball-nosed end milling, CIRP Annals - Manuf. Technol., 52 (2003), 49-52.

[10] Quinsat Y., Sabourin L., Lartigue C.: Surface topography in ball end milling process: Description of a 3D surface roughness parameter, J. Mat. Proc. Technol., 195 (2008), 135-143. 


\section{Acknowledgement}

Presented results have been achieved within 1/0500/12 VEGA Project: Research on Quality Improvement when Milling Formed Surfaces by Advanced Coated Tools, supported by Ministry of Education, Science, Research and Sports of Slovakia.

\section{BADANIE WYSOKOŚCI ŚLADU OBRÓBKOWEGO PODCZAS OBRÓBKI FREZEM PALCOWYM POWIERZCHNI KSZTALTOWYCH}

\section{Streszczenie}

W pracy przedstawiono model wysokości śladu obróbkowego w procesie obróbki frezem palcowym o zarysie kulistym. W wielu operacjach frezowania narzędzie wykonuje stopniowe ruchy, tworząc przylegające do siebie ślady obróbkowe. W rezultacie, jeżeli obróbka odbywa się frezem palcowym o zarysie kulistym, po obróbce pozostają małe występy materiału na krawędziach sąsiednich śladów obróbkowych. Procedura ta przedstawia zastosowanie oprogramowania do oceny wysokości zarysu śladu obróbkowego w procesie frezowania. Wysokość występów jest badana na powierzchniach mających różny wskaźnik krzywizny i różną orientację. Opracowano matematyczny model do przewidywania występów obróbkowych w odniesieniu do osiowych i promieniowych głębokości skrawania, krzywizny powierzchni i średnicy narzędzia. Zastosowana technika DOE Taguchiego wyznacza wartości parametrów procesu, które prowadzą do najkrótszego czasu obróbki i osiagnięcia pożądanej tekstury powierzchni.

Słowa kluczowe: frazowanie, warunki skrawania, wysokość występu, tekstura

DOI:10.7862/rm.2013.18

Otrzymano/received: 10.05 .2013

Zaakceptowano/accepted: 25.07.2013 